\section{Bogmærke i Dalbybogen}

\author{
af lektor Joy Boutrup, Designskolen i Kolding
}

I Dalbybogen (Gl. Kgl. S1325 4º sidder et bogmærke af en type, som var almindelig i middelalderen og renæssancen. Bogmærket er ikke fastgjort til bogen. Det er et flerstrenget bogmærke, som især blev anvendt $\mathrm{i}$ bibler og bønnebøger. Denne type består af en knop eller en lille tværpind, hvor der er fastgjort flere flettede eller vævede bånd. Disse bånd har ofte forskellig farve og en kvast eller en lille kugle af tekstil eller metal i de løse ender, som hjælper med at holde båndet udstrakt i selve bogen. Knoppen eller tværpinden sidder ved brugen udenfor bogblokken og de enkelte strenge lægges ind forskellige steder i bogen, således at de løse ender hænger ud nedenfor siden.

Denne type bogmærker kan ses på utallige religiøse malerier og $\mathrm{i}$ illuminerede bøger fra det 14. til det 16 . århundrede og findes desuden nævnt $\mathrm{i}$ forskellige skriftlige kilder, f.eks. i beskrivelser af indbindinger, i regnskaber og biblioteksfortegnelser.

Her nævnes blot nogle få af disse afbildninger: Heinrich von Werl triptych, "Den læsende Sct. Barbara", (formodentlig Robert Campin ca. 1435), "Den læsende Magdalena", Rogier van der Weiden 1435, ’Pengeudlåneren og hans kone”, Quentin Metsys 1514.

I modsætning til andre

religioner, hvor bogrullen har været væsentligere, har bogen altid spillet en stor rolle i den kristne liturgi. En bog eller codex kan - modsat rullen - læses diskontinuerligt, ja den opfordrer ligefrem til det. I den kristne liturgi skal der ved hver andagt læses flere steder $\mathrm{i}$ biblen eller bønnebogen og bestemte steder skal findes flere gange. ${ }^{1}$

Bogmærket var således nødvendigt for at man hurtigt kunne finde frem og tilbage under andagten, det være sig privat eller $\mathrm{i}$ forbindelse med en gudstjeneste. De tidligste bogmærker, som er ligeså gamle som selve ideen om en codex, var som regel fastgjort til kapitælbåndet. I løbet af det 13. århundrede blev der udviklet flere hjælpemidler til at finde bestemte steder i biblen som f.eks. kalender, indeks, side- eller folio nummerering, foruden de flerstrengede bogmærker, som ikke var sat fast i bogen.

Der findes flere betegnelser for flerstrengede bogmærker i de skriftlige kilder, ${ }^{2}$ nogle af de vigtigste er:

Registrum; Pippe garnie de seigneaulx eller Seigneaux de plusieurs soyes (1416); Signaculum.

Den runde knop er ofte afbildet som guldsmedearbejde, rigt udsmykket med perler og ædelstene, som det f.eks. kan ses på flere af van Eycks malerier, bl.a. altertavlen i Ghent. Der findes imidlertid også flere eksempler på mere ydmyge bogmærker, hvor knoppen er fremstillet af tekstil. Det kan være $\mathrm{i}$ form af en lille pude af silke eller en kunstfærdig knude. 


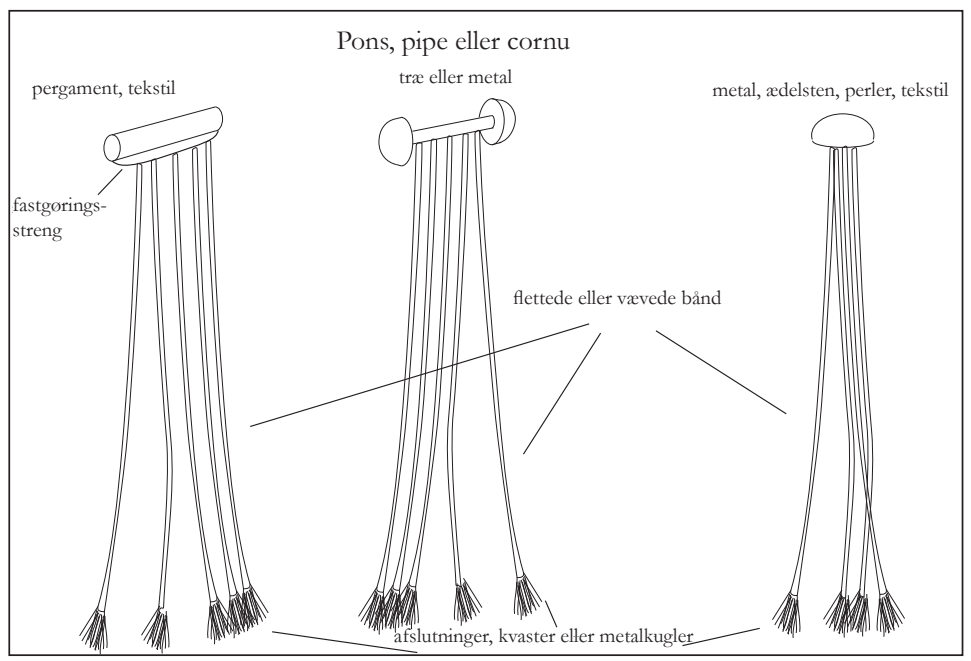

Bogmarkernes opbygning og betegnelser.

Tværpinden, som ofte er tilpasset bogens tykkelse, kaldes i forskellige kilder henholdsvis "pons", "pipe" eller "cornu". Den kan f.eks. være af træ, metal eller rullet pergament og eventuelt være overtrukket med tekstil i en possementteknik. I de tidlige typer med tværpind er strengene sat fast direkte på pinden. I de senere typer er strengene fastgjort til en ekstra snor, som går fra den ene ende af pinden til den anden. Denne sidste metode giver større fleksibilitet og mindre risiko for beskadigelse af bogens sider.

Tværpinden på bogmærket $\mathrm{i}$

Dalbybogen er ca. $4 \mathrm{~cm}$ lang og dermed meget kortere end bogens tykkelse. Der er en afsluttende knop i begge ender. Knopperne er kantede og ender i en facetteret, afrundet spids. Midt på skaftet mellem knopperne sidder en dobbelt vulst. Der har sikkert oprindeligt været to strenge fastgjort til hver side for vulsten, dvs. fire strenge i alt. $\mathrm{Nu}$ er der kun to hele og en halv af de flettede snore tilbage. Enderne er åbne og der er ingen spor af eventuelle afslutninger i form af kvaster eller kugler. Fletningernes oprindelige fastgøring til tværpinden kan ikke ses, da der er syet og viklet med ufarvet hør omkring skaftet, midtervulsten og fastgøringerne. Det er sikkert en senere reparation, men strengene har med sikkerhed været anbragt direkte på tværpinden.

Træsorten ser ud til at være af en finkornet, kompakt type, som f.eks. buksbom eller pæretræ. Snorene er flettede af ubleget hør og rød silke. De er fremstillet i løkkefletning med tre løkker, to af hør og én af rød silke. Bogmærkets udformning gør det sandsynligt ud fra de sammenlignelige eksemplarer, at det stammer fra det 14. århundrede og måske er samtidigt med en af ændringerne af bogens indbinding. Ryggen viser rester af en rød skindindbinding. Oven på skindet, men under de nuværende metalkanter, stikker små rester af et flerfarvet, mønstervævet silkestof, 


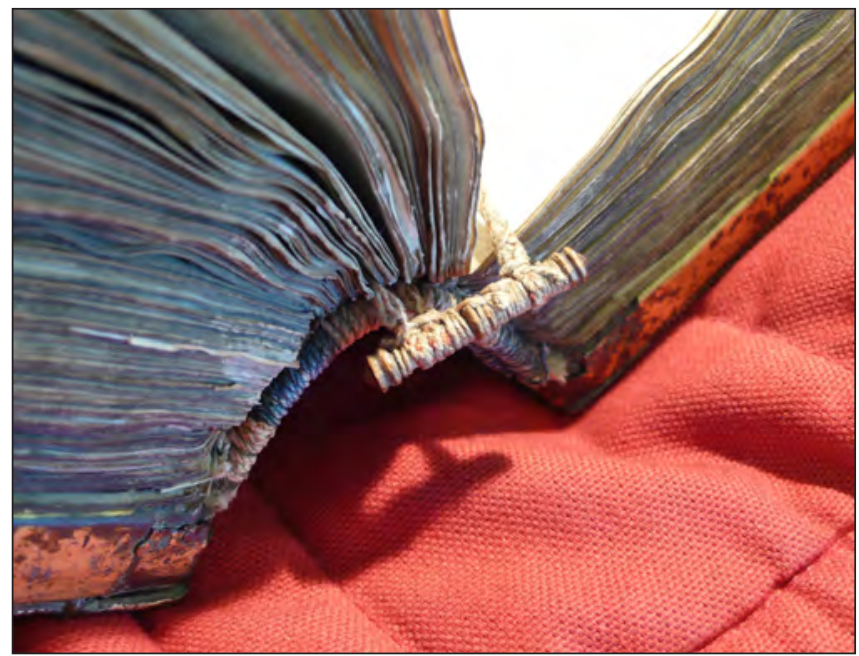

Bogmarket $i$ Dalbybogen. Dalby i Skane var bispesade en kort periode fra ca. 1060. Fra klosterbiblioteket stammer Dalbybogen, et evangeliehaindskrift fra slutningen af 1000-tallet og dermed Nordens aldste (Det Kongelige Bibliotek).

som har været bogens bind indtil for- og bagside blev beklædt med forgyldte og forsølvede metalplader fra det 12.- 13. århundrede.

Da metalindbindingen viser tegn på, at have tilhørt en anden bog først, kan bogmærket meget vel være samtidigt med deres anvendelse til indbinding af Dalbybogen.

Fletningerne her er alle ens og er af en meget simpel konstruktion. Bogmærker fra det 17. århundrede har generelt flere strenge med forskellig farve. Desuden er både "pons" og strenge Side med streng.

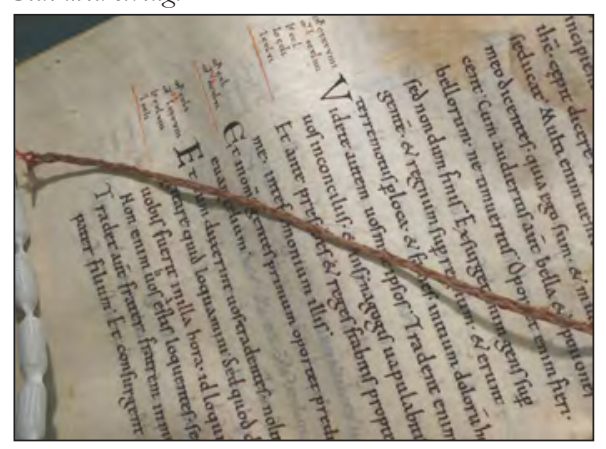

på disse senere bogmærker ofte udført mere kunstfærdigt og med flere farver silke. Desværre er bogmærkerne ikke altid registrerede eller nævnt i beskrivelsen af bøgerne i mange af de store bogsamlinger og biblioteker med bøger fra middelalder og renæssance. De kan derfor let forsvinde ved uopmærksomhed eller tyveri.

De fleste af de bevarede, flerstrengede bogmærker med, stammer fra slutningen af det 16. og begyndelsen af det 17. århundrede ofte $i$ forbindelse med en samtidig indbinding med broderede eller billedvævede tekstiler. Der findes flere bøger af denne type i Victoria \& Albert Museum, British Library og i Metropolitan Museum of Art, hvor bogmærkerne er bevaret. De kan ses på de pågældende samlingers hjemmesider. Enkelte eksemplarer fra senmiddelalderen er dog lokaliseret indtil nu. Her kan f.eks. nævnes ét, som er fundet $i$ en incunabula $i$ Weimar $^{3}$ og ét fundet løst under korstolene i klostret 


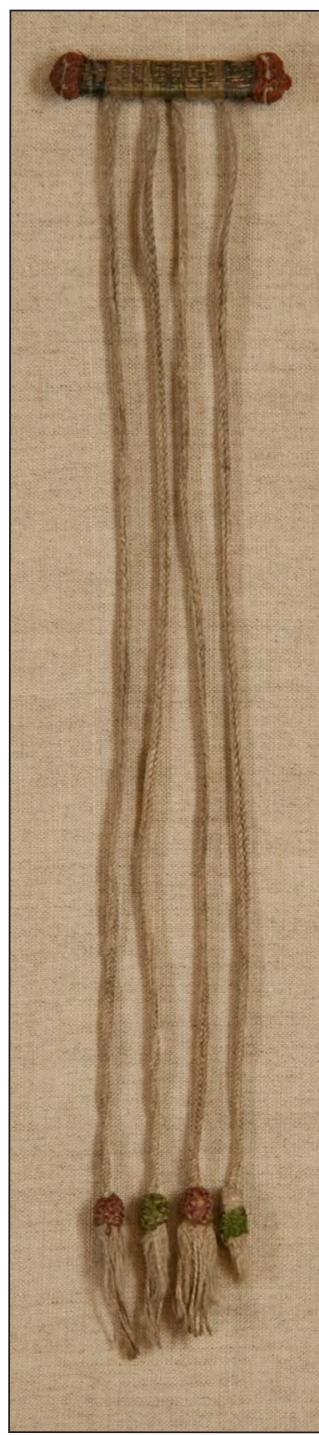

Bogmarke fra Wienhausen. i Wienhausen. ${ }^{4}$

Disse to minder om bogmærket $i$

Dalbybogen, ved at tværpinden er af snittet eller drejet træ, og ved, at der kun er ca. fire strenge. Bogmærket fra Weimar har en snittet tværpind uden dekorationer, hvortil der er fastgjort fire smalle vævede bånd formodentlig af hør og farvet uld. Bogmærket fra klostret i Wienhausen har en træpind overtrukket med syning i rød silke på de to knopper for enden af pinden og med gylden og grøn silke på midterstykket. Der er fire flettede snore af hvid hør af samme struktur, som snorene på bogmærket i Dalbybogen. Klostret i Wienhausen er øvrigt $\mathrm{i}$ besiddelse af hele tre flerstrengede bogmærker fra senmiddelalderen, de to andre er henholdsvis ét med en dekorativ knude med fire flettede snore af hvid hør og ét bestående af en oval silkepude med tre flettede

blå-hvide snore. ${ }^{5}$

Flere af

disse bogmærker er bemærkelsesværdigt velbevarede, da de konstant har siddet $\mathrm{i}$ den bog, de hørte til. Bogen har beskyttet dem mod lys og støv. Ofte er enderne, som har hængt uden for bogen, mere medtagne og snavsede. Endringer i skikkene har beskadiget denne del af bogmærkerne; de var forholdsvis uberørte dengang bøgerne blev opbevaret liggende, men de udhængende dele blev let beskadiget, når bøgerne skulle stå på højkant. Langt de fleste bevarede bogmærker af denne type findes i forbindelse med bøger, som har tekstile, dvs.

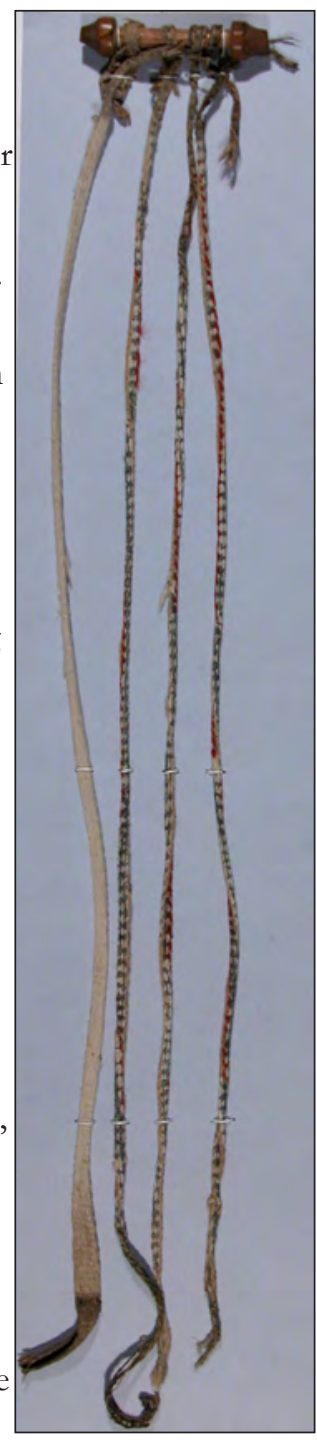

Bogmarke fra Weimar. broderede eller vævede indbindinger. Denne type indbindinger var meget udbredt fra slutningen af det 16. århundrede til midten af det 17 . århundrede.

I den anglikanske og den katolske kirke anvender man stadig flerstrengede bogmærker. De består 
som regel af seks smalle, vævede bånd i forskellige farver med et topstykke af skind eller stof.

\section{Noter}

1 Peter Stallybrass, side 42 - 48.

2 Franz Bock, side 43 -44.

3 Herzogin Anna Amalia Bibliothek, Weimar, Moguntinum, inc. 144 , trykt 1496, Eva Raffel, side 128.

4 Inventarnummer Wien. Hc 2, 14. århundrede, Jeffrey Hamburger, side 226

5 Kloster Wienhausen, inventarnummer Hs 51 og Hc 0.
Litteratur

Bock, Franz: Geschichte der Liturgischen Gewänder des Mittelalters, Vol. III, 1907, optrykt Graz 1970.

Raffel, Eva: Welt der Wiegendrucke, Udstillingskatalog 2007-2008, Anna Amalia Bibliothek, Weimar.

Stallybrass, Peter: Books and Scrolls i Books and Readers in early modern England, I. Anderson \& E. Sauer, University of Pensylvania Press, 2002.

Hamburger, Jeffrey: Reading representations i Die lesende Frau, Herzog August Bibliothek Wolfenbüttel, 2009. 